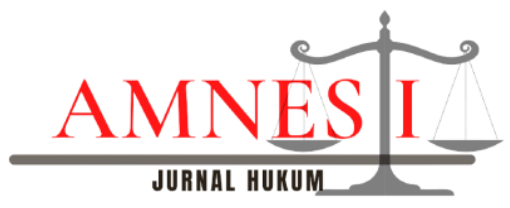

\title{
Telaah Kritis Kebiri Kimia sebagai Pidana Tambahan Bagi Pelaku Pedofilia
}

\section{Galih Bagas Soesilo}

Universitas Muhammadiyah Purworejo, Purworejo, Indonesia

*email: galihbsoesilo@gmail.com

DOI: https://doi.org/10.37729/amnesti.v3i1.892

Submitted: November 2020 Revised: Desember 2020

Accepted: Janauari 2021

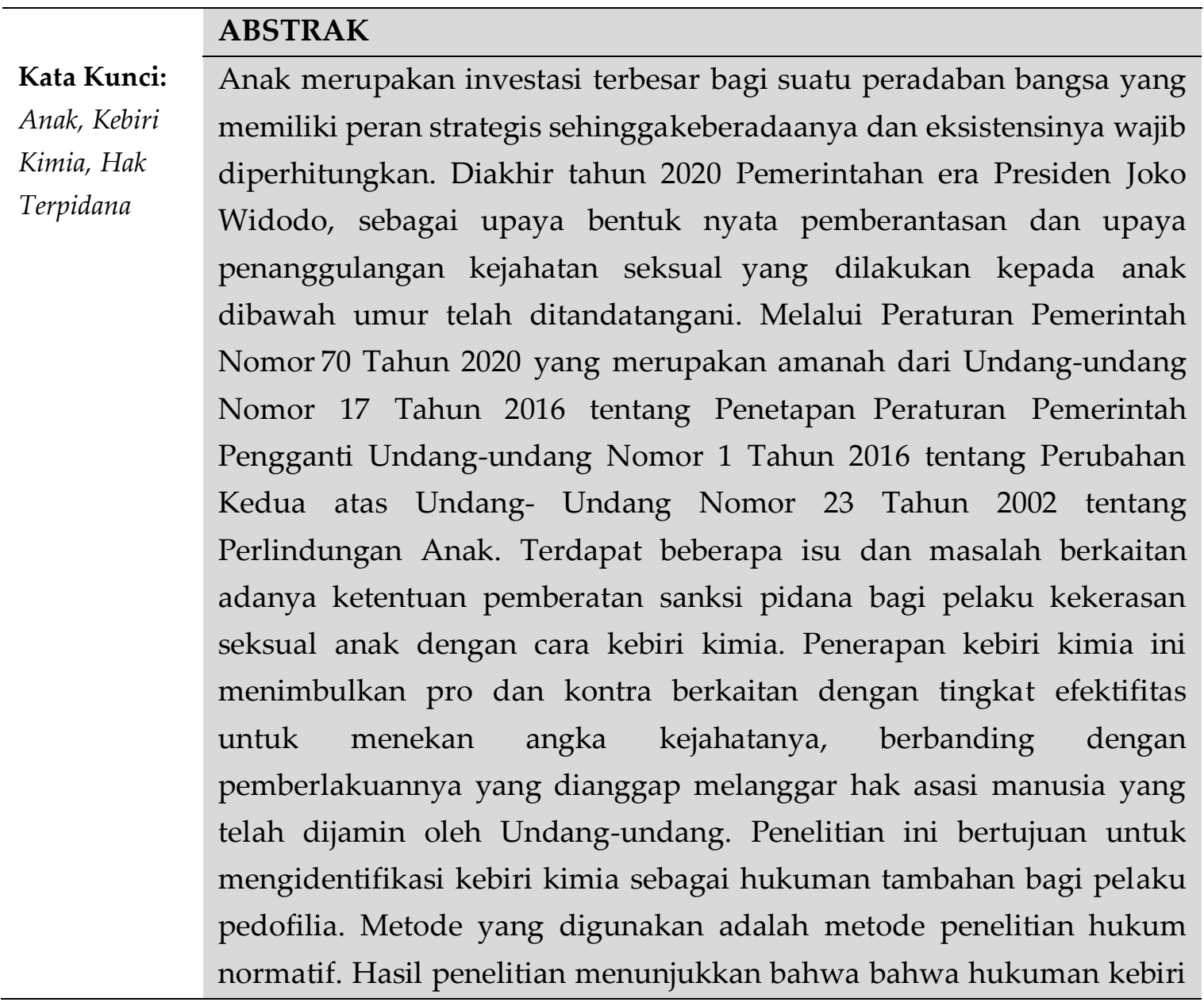


sebagai hukuman tambahan diharapkan memberikan efek jera atau balasan yang dianggap pantas serta diharapkan memperbaiki kelakuan terpidana setelah selesai menjalani pidana pokoknya. Dalam pelaksanaan hukuman kebiri kimia tidak dilakukan secara serta merta. Melainkan melalui tiga tahap yaitu penilaian klinis, kesimpulan dan pelaksanaan. Sehingga ada potensi pelaku tindak pidana kejahatan seksual anak tidak dijatui hukuman kebiri kimia.

\section{Keywords : \\ Children, \\ Chemical \\ Castration, \\ Rights of the \\ Convict}

\section{ABSTRACT}

Children are the biggest investment for a nation's civilization that has a strategic role so that its existence and existence must be taken into account. At the end of 2020, the government of President Joko Widodo, as a tangible form of eradicating and preventing sexual crimes committed against minors, has been signed. Through Government Regulation Number 70 of 2020, which is a mandate from Law Number 17 of 2016 concerning Stipulation of Government Regulation instead of Law Number 1 of 2016 concerning the Second Amendment to Law Number 23 of 2002 concerning Child Protection. There are several issues and problems related to criminal sanctions for perpetrators of sexual violence against children through chemical castration. The application of chemical castration raises pros and cons related to the effectiveness of reducing the crime rate, compared to its implementation, which is considered to violate human rights guaranteed by law. This study aims to identify chemical castration as an additional punishment for paedophiles. The method used is a normative legal research method. The study results indicate that castration as an additional punishment is expected to provide a deterrent effect or a response that is considered appropriate and is expected to improve the convict's behaviour after completing his main sentence. In the implementation of chemical castration, punishment is not carried out immediately. Rather, it goes through three stages, namely clinical assessment, conclusion and implementation. So there is a potential that perpetrators of child sex crimes are not subject to chemical castration.

\section{PENDAHULUAN}

Presiden Joko Widodo meneken Peraturan Pemerintah Nomor 70 Tahun 2020 tentang Tata Cara Pelaksanaan Tindakan Kebiri Kimia, Pemasangan Alat Pendeteksi Elektronik, Rehabilitasi, dan Pengumuman Identitas Pelaku Kekerasan Seksual terhadap Anak. Hal ini merupakan Kado akhir tahun 2020 dari pemerintah Indonesia, sebagaimana bentuk pro-aktif hadirnyanegara atas pemcegahan dan penenggulangan tindakan kekerasan seksual kepaada anak. 
Terbitnya Peraturan Pemerintah tersebut telah melalui proses yang begitu panjang yang sebelumnya sebagai bentuk aksi reaktif atas keperihatinan segenap elemen Indonesia atas tingginya kasus kekerasan \& kejahatan seksual terhadap anak. Peraturan Pemerintah Nomor 70 Tahun 2020 tersebut merupakan turunan dari Pasal 81A ayat (4) dan Pasal 82A ayat (3) Undangundang Nomor 17 Tahun 2016 tentang Penetapan Peraturan Pemerintah Pengganti Undang-undang (Perppu) Nomor 1 Tahun 2016 tentang Perubahan Kedua atas Undang- Undang Nomor 23 Tahun 2002 tentang Perlindungan Anak.

Kejahatan seksual anak yang pernah terjadi dan sangat menyita perhatian publik, ialah kasus seorang remaja perempuan berusia 14 tahun, warga Lampung Timur melaporke Polda Lampung karena diperkosa oleh 12 orang. Akibat pemerkosaan tersebut korban menderita sakit pada bagian rahimnya terjadi pada tanggal 22 April 2014 (Eni Muslihah, 2014). Selanjutnya ka sus yang terjadi pada Oktober 2015, inisial AAP 12 tahun, seorang siswi di Madrasah Tsanawiyah Al-Mubarak, Jakarta Pusat ditemukan mati mengenaskan setelah dibunuh dan diperkosa oleh RZ di areal Perhutani Desa Pangaur, Jasinga, Kabupaten Bogor (Metro, 2015). Kemudian kasus yang menyita keperihatinan publik yaitu kasus pencabulan dan pembunuhan yang menimpa anak berusia 14 tahun yang bernama Yuyun murid SMP pada Sabtu 2 April 2016 yang diperkosa dan dibunuh oleh 14 orang diladang sawit yang saat itu korban dalam perjalanan pulang dari sekolah (Jambi Tribunnews, 2016).

Pengertian hukuman kebiri kimia sebagaimana tertuang didalam peraturan tersebut adalah pemberian zat kimia melalui penyuntikan atau metode lain, yang dilakukan kepada pelaku yang pernah dipidana karena melakukan kekerasan atau ancaman kekerasan memaksa anak melakukan persetubuhan dengannya atau dengan orang lain, sehingga menimbulkan korban lebih dari 1 (satu) orang, mengakibatkan luka berat, gangguan jiwa, penyakit menular, terganggu atau hilangnya fungsi reproduksi, dan/atau korban meninggal dunia, untuk menekan hasrat seksual berlebih, yang disertai rehabilitasi (Ilyas, 2015). Muncul pro dan kontra tentang adanya ketentuan pidana tambahan tersebut. Ada yang mendukung dan layak untuk segera diaplikasikan dan adapula pihak yang kurang sepakat dan bahkan menentang dengan prespektif melihat hak-hak kemanusiaan yang melekat dari pelaku kejahatan. 


\section{METODE PENELITIAN}

Metode penelitian dalam penentuannya dipandang penting karena ada hubungannya erat antara jenis penelitian dengan sistematika dan metode, serta analisis data guna mencapai nilai validasi yang tinggi baik data yang dikumpulkan maupun hasil akhir penelitian (Dillah, 2013).

Peneltian ini berfokus pada penelitian hukum normatif karena mengkaji dan menganalisis berbagai peraturan perundang- undangan di Indonesia. Oleh karena itu untukmemperoleh hasil penelitian, data yang dipergunakan adalah data sekunder. Kemudian bahan hukum yang digunakan diantaranya adalah bahan hukum primer yaitu peraturan perundang-undangan, bahan hukum sekunder yaitu buku dan jurnal yang secara khusus membahas mengenai sanksipidana kebiri kimia, selain itu penulis juga menggunakan bahan hukum tersier yaitu artikel maupun berita yang terkait berasal dari internet sebagai pelengkap bahan hukum dalam penelitian ini (Ishaq, 2017).

\section{HASIL DAN PEMBAHASAN}

Penjatuhan hukuman pidana terhadap pelaku kejahatan seksual terhadap anak sebelumnya telah diatur didalam sumber hukum pidana negara Indonesia (KUHP), dan Undang-undang tentang perlindungan anak, telah memuat sanksi hukum bagi pelaku pemerkosaan, akan tetapi terdapat beberapa kelemahan yang timbul terhadap sanksi hukum. Sanksi pidana terhadap pelaku pemerkosaan tersebut dirasa tidak memberikan efek jera bagi pelaku kejahatan seksual terhadap anak, bahkan tak jarang pelaku mengulangi perbuatannya tanpa rasa iba kepada korban.

Anak menjadi kelompok yang sangat rentan terhadap kekerasan seksual karena anak selalu diposisikan sebagai sosok lemah atau yang tidak berdaya dan memiliki ketergantungan yang tinggi dengan orang-orang dewasa di sekitarnya. Hampir dari setiap kasus yangberhasil terungkap pelaku kejahatan merupakan orang-orang yang dekat dengan korban. Tidak jarang bahwa pelaku adalah kebanyakan dari lingkungan keluarga atau lingkungan sekitar anak tinggal, antara lain di dalam rumahnya sendiri, sekolah, dan lingkungan sosial anak. Dengan kata lain, siapa pun dapat menjadi pelaku kekerasan seksual terhadap anak atau pedofilia (Ino Novian, 2015). 
Seperti kasus yang terbaru ini yang terjadi wilayah hukum Polresta Deliserdang, Sumatra Utara dimana ada seorang ayah kandung yang telah berulang kali melecehkan anak kandungnya yang masih dibawah umur sebanyak 20 kali. Tentunya dalam aturan hukum yang telah ada saat ini, pelaku dapat dijerat hukuman tambahan berupa kebiri kimia (Banjarmasinpost, 2021). Dalam kasus tersebut ditumukan sebuah fakta bahwa kakak pelaku (15 tahun) juga terlibat kejahatan kekerasan seksual terhadap adik kandungnya.

Dalam menyikapi hal ini terhad pelaku kejahatan seksual anak yang dilakukan oleh anak dibawah umur, maka Peraturan Pemerintah Nomor 70 Tahun 2020 yang memerintahkan adanya hukuman kebiri kimia dan hukuman tambahan yang termuat didalamnya, tidaklah diberlakukan. Ada sejumlah syarat bagi pelaku kekerasan seksual terhadap anak di bawah umur yang akan dijatuhi hukuman kebiri. Syarat umum bagi pelaku kekerasan seksual terhadap anak di bawah umur yang akan di jatuhkan hukuman kebiri (Kurniawan, 2017).

1. Pertama pelaku yang akan dikebiri divonis hukuman pidana minimal 5 tahun dan maksimal 20 tahun.

2. Kedua keputusan hakim yang mutlak di berika kepada pelaku atau terdakwa, karna keputusan hakim menjadi syarat utama dalam memberikan penetapan sanksi kebiri kimia.

3. Ketiga hukuman kebiri diberikan apabila pelaku sudah dewasa atau sudah berumur dia atas 18 tahun.

Untuk mengenal pasti apa yang dimaksud dengan anak, maka mesti merujuk daripada pengertian anak itu. Menurut Peraturan perundangundangan di Indonesia ketentuan batas kedewasaan merupakan tolak ukur pengertian anak (Hikmah et al., 2015), diantaranya disebutkan pada:

1. Anak menurut ketentuan umum Pasal 1 ayat 2 Undang-Undang Nomor 4 Tahun 1979 tentang Kesejahteraan Anak disebutkan bahwa anak adalah seorangyang belum mencapai umur 21 (dua puluh satu) tahun dan belum kawin.

2. Anak menurut Undang-Undang Nomor 3 Tahun 1997 tentang Pengadilan Anak dinyatakan bahwa anak adalah orang yang dalam perkara anak nakal telah mencapai umur 18 (delapanbelas) tahun dan belum pernah kawin.

3. Dalam Kitab Undang-Undang Hukum Pidana menyebutkan anak pada batasan belum cukup umur dalam Pasal 45 yang menyatakan dalam 
menuntut orang yang belum cukup umur karena melakukan perbuatan sebelum umur enam belas tahun.

4. Anak menurut Kitab Undang-Undang Hukum Perdata, sebagaimana pada Pasal 330 Kitab Undang-Undang Hukum Perdata (KUHPerdata) menyatakan bahwa belum dewasa adalah mereka yang belum mencapai umurgenap dua puluh satu tahun, dan tidak lebih dahulu telah kawin.

Yang dimaksudkan dengan anak dalam pembahasan ini ialah istilah anak yang diartikan oleh Undang-undang (UU) No 35 tahun 2014 tentang Perubahan Atas Undang- undang No 23 Tahun 2002 tentang Perlindungan Anak, terlihat bahwa yang dimaksud dengan anak adalah orang yang belum beru- sia 18 tahun. Pasal 1 dalam UU No 35 tahun 2014 menyatakan bahwa yang dimaksud dengan anak adalah seseorang yang belum berusia 18 tahun, termasuk anak yang masihdalam kandungan. Ketentuan pengertian anak juga telah diatur di Peraturan Pemerintah Nomor 70 Tahun 2020 Pasal 1 ayat (1).

Sepanjang sejarah peradaban manusia, praktik pengebirian sudah dilakukan manusia bahkan jauh sebelum tercatat dalam sejarah. Kebiri kadang kala dilakukan atas dasar alasan keagamaan atau sosial di budaya tertentu di Eropa, Timur Tengah, Asia Selatan, Afrika, dan Asia Timur (Munthe, 2016). Setelah peperangan, pemenang biasanya mengebiri dengan memotong penis dan testis mayat prajurit yang telah dikalahkan sebagai tindakan simbolis menggambil kekuatan dan keperkasaan mereka. Kemudian tindakan kebiri dipakai untuk menjaga dan melindungi istri ketika mereka (para kaisar) bertugas di kerajaan Timur Tengah, dan pada masa purba, pengebirian juga melibatkan pemotongan seluruh alat kelamin pria, baik testis sekaligus penis. Praktik ini sangat berbahaya dan kerap mengakibatkan kematian akibat pendarahan hebat atau infeksi, sehingga dalam beberapa kebudayaan seperti Kekaisaran Byzantium, pengebirian disamakan dengan hukuman mati (Rodliyah et al., 2020).

Hukuman kebiri diera sekarang ialah hukuman kebiri kimia seperti amanah dari Peraturan Pemerintah Nomor 70 Tahun 2020 Pasal 1 ayat (2). Walaupun dari sudut proses dirasa masih ringan dari pada kebiri yang dilakukan pada zaman dahulu, tetapi dipahami bahwa hukuman kebiri kimia dilihat dari sudut kacatama Hak Asasi Manusia, melang-gar Pasal 33 ayat (1) Undang-Undang No- mor 39 Tahun 2009 Tentang Hak Asasi Manusia, yang menyatakan bahwa setiap orang berhak untuk bebas dari penghukuman yang kejam, tidak manusiawi, merendahkan derajat dan martabat kemanusiannya. 
Hukuman kebiri akan menimbulkan efek malu tidak hanya bagi pelaku kekerasan seksual anak namun juga keluarga pelaku. Belum lagi, pelaku tidak bisa meneruskan keturunan akibat dari hukum kebiri tersebut. Kedua hal tersebut bisa membuat pelaku mengalami tekanan yang luar biasa dan tidakada jaminan bahwa pelaku tidak akan mengulangi lagi perbuatanya.

Perlu dikatahui bahwa, didalam Peraturan Pemerintah Nomor 70 Tahun 2020 Pasal 5 menyatakan hukuman kebiri kimia diberlakukan paling lama selama dua tahun yang dilakukan segera setelah pelaku selesai menjalankan pidana pokok (lihat juga Pasal Pasal 9 huruf c PP No. 70 Tahun 2020).

Menurut Amnesti Internasional, Hukuman kebiri kimia melanggar hukum internasional akan larangan tindak penyiksaan, dan perlakuan atau penghukuman lainnya yang kejam, tidak manusiawi, atau merendahkan martabat manusia sebagai mana yang di atur oleh Kovenan Internasional tentang Hak-hak Sipil dan Politik (ICCPR). Proses pemandulan yang sifatnya sementara inimembuat hak para pelaku kejahatan seksual memiliki keturunan terhapus (Rodliyah et al., 2020).

Selain lembaga diatas yang memang langsung yang bersinggungan dengan segalasesuatu yang berhubungan dengan HakAsasi Manusia, adapula kritisasi yang disampaikan oleh beberapa lembaga yang patut untuk didengar pendapatnya seperti, Pendapat dari Majelis Ulama Indonesia yang secara tegas menolak hukuman kebiri kimia bagi pelaku kejahatan seksual terhadap anak (pedofilia), alasanya didasari bahwa tinda- kan kebiri kimia adalah bentuk upaya merubah ciptaan yang Maha Kuasa (IDN Times, 2021). Selanjutnya Pengurus Wilayah Nahdlatul Ulama (PWNU) Jawa Timur turut mengkaji pemberlakuan hukum kebiri bagi pelaku kejahatan seksual di kalangan anak adalah haram, hal ini didasari bahwa mayoritas ulama mensyaratkan takzir tidak berdampak negatif, sementara dari sisi kesehatan kebiri kimia tidak hanya merusak organ reproduksi tapi dapat merusak organ yang lain (NUonline, 2019). Kemudian dari salah satu Ortom Muhammadiyah yaitu PP Nasyiatul Aisyiyah (NA) juga ikut memberikan pendapat, yaitu supaya dengan diberlakunya PP No. 70 Tahun 2020 harus dikritisi dengan melihat dua sudut pandang yang berbeda, yaitu dari sudutpandang korban hukuman kebiri kimia adalah hal yang layak dan pantas diberikan, sementara untuk pelaku sendiri hukuman kebiri kimia akan memberikan trauma tersendiri, oleh karena itu mesti ada bimbingan dari segi psikologis (Muhammadiyah.or.id, 2021). 
Perihal pelaksanaan hukuman kebiri kimia dalam amanahnya Peraturan Pemerintah Nomor 70 Tahun 2020 Pasal 9 huruf b, yang mana tertuliskan bahwa Jaksa memerintahkan Dokter untuk melakukan pelaksanaan tindakan kebiri kimia, hal ini memerlukan diskusi dan pembahasan yang lebih mendalam, mengingat bahwa profesi Dokter terikat dengan kode etik dan sumpah profesinya iaitu tidak melakukan sesuatu yang dapat merusak kesehatan pasien (IDN Times Bali, 2021).

Bukan namanya pidana apabila sifatnya tidak memaksa dan terkesan melanggar HAM. Penjatuhan pidana kepada orang yang dianggap bersalah menurut hukum pidana, secara garis besar dapat bertolak dari perbuatan terpidana dimasa lalu dan/ atau untukkepentingan dimasa yang akan datang. Apabila bertolak dimasa lalu, maka tujuan pem-idanaan adalah sebagai balasan, tetapi berorientasi dimasa yang akan datang, maka tujuan pidana adalah untuk memperbaiki ke- lakuan terpidana. Selanjutnya dikenal dengan adanya teori relatif atau teori tujuan, tujuan pemidanaan adalah mencegah kejahatan. Teori relatif atau teori tujuan juga disebut teori utilitarian, lahir sebagai reaksi terhadap teori absolut. Secara garis besar, tujuan pidana menurut teori relatif bukanlah sekedar pembalasan, akan tetapi untuk mewujudkan ketertiban di dalam masyarakat. Jadi, tujuan pidana menurut teori relatif adalah untuk mencegah agar ketertiban di dalam masyarakat tidak terganggu. Dengan kata lain, pidana yang dijatuhkan kepada pelaku kejahatan bukanlah untuk membalas kejahatannya, melainkan untuk mempertahankan ketertiban umum (Fitri Wahyuni, 2013).

Perlu diketahui bersama, bahwa penjatuhan hukuman tidak serta merta setiap pelaku kejahatan seksual anak langsung bisa dikenai kebiri kimia. Ada beberapa proses ataupun tahapan sebelumnya menjelankan perintah hakim yang telah berkekuatan hukum tetap. Tahapan tersebut dibagi menjadi tiga tahap yaitu penilaian klinis, kesimpulan dan pelaksanaan. Ketiga tahapan tersebut dilakukan secara runtut dan dilakukan oleh ahlimemiliki kompetensi di bidang medis dan psikiatri untuk menentukan layak atau tidak layaknya pelaku kejahatan seksual anak dijatuhi hukuman kebiri. Disini peran dan fungsi negara dapathadir dan dirasakan oleh segenap warga negara Indonesia tanpa terkecuali, terlepas itu pelaku kejahatan sekalipun (Dirgantara et al., 2017). 


\section{KESIMPULAN}

Upaya pemerintah untuk memberikan efek jera pelaku kejahatan seksual anak dengan memberikan hukuman tambahan yang tidaklah ringan bagi pelaku kejahatan perlu diapresiasi. Dengan telah diterbitnya segenap peraturan dari Undang-undang perlindungan anak dan juga terbitnya Peraturan Pemerintah Nomor 70 Tahun 2020 di- harapkan mampu menekan dengan maksimal angka penurunan kejahatan seksual anak. Beberapa teknis birokrasi prihal pelaksanaan hukuman kebiri kimia yang telah disampaikan diatas, semoga segera terselesaikan sampai dengan tahapan teknis dan tidak ada pihak yang merasa dibebani dengan tugas tersebut. Serta perlu adanya evaluasi dan kajian-kajian kembali apabila kemudian hari telah ada pelaku yang telah dihukum kebiri kimia.

\section{DAFTAR PUSTAKA}

Banjarmasinpost. (2021). Ayah Bejad Siap Dihukum Kebiri Gegara Tergiur Kemolekan Tubuh Anak Kandung, Rudapaksa 20 Kali. , Https://Banjarma- Sin.Tribunnews.Com/2021/01/22/Ayah-Bejad-Siap-DiHukum-Kebiri-Gegara-Tergiur-Kemolekan-Tubuh-Anak- Kandung-Rudapaksa20-Kali?Page=all, 1.

Dillah, S. \& P. (2013). Metode Penelitian Hukum.

Dirgantara, M. A., Kallo, S., Syahrin, A., \& Bariah, C. (2017). Analisis Yuridis Kebijakan Pemidanaan dengan hukuman Kebiri Terhadap Pelaku Pedofilia. USU Law Journal, 5(1), 119-127.

Eni Muslihah. (2014). Gadis 14 Tahun Diperkosa 12 Orang. Kompas, 1.

Fitri Wahyuni. (2013). Hukuman Kebiri Terhadap Pelaku Tindak Pidana Pemerkosaan Anak Dan Kaitannya Dengan Hak Asasi Manusia. Jurnal Hukum Dan Peradilan, 6(2), 286.

Hikmah, N., Jauhari, I., \& Hasyim, S. (2015). Analisis Terhadap Peraturan Batas Umur Anak Ditinjau Menurut Peraturan Perundang-Undangan dan Putusan Hakim dalam Perkara Perdata di Pengadilan Negeri. Jurnal Ilmu Hukum, 3(1), 66-75.

IDN Times. (2021). Tolak Hukuman Kebiri Kimia, MUI: Itu Mengubah Ciptaan Allah SWT. Https://Www.Idntimes.Com/News/Indonesia/Fitang-AdHitia/Tolak-Hukuman-Kebiri-Kimia-Mui-Itu-Mengubah-Ciptaan-Allah-Swt/1.

IDN Times Bali. (2021). Predator Seksual Anak Dikebiri Kimia, Ini Tanggapan

IDI. Https://Bali.Id- Ntimes.Com/News/Indonesia/Lia-Hutasoit-1/KebiriKimia-Predator-Seksual-Anak-Idi-Ungkap-Efeknya- Bagi-Tubuh-RegionalBali/3, 3 .

Ilyas, S. (2015). Sanksi Kebiri Kimiawi Bagi Pelaku Pedofilia dalam Prespektif 
Hukum di Indonesia. Jurnal AL-MURSALAH, 1(2), 21-29.

Ino Novian. (2015). Kekerasan Seksual Terhadap Anak: Dampak dan

Penanganannya, dalam Pusat Kajian dan Pengembangan Kesejahteraan Sosial. Sosio Informa, 1(1), 13-28.

Ishaq. (2017). Metode Penelitian Hukum Dan Penulisan Skripsi, Tesis, Serta Disertasi. In ALFABETA, cv.

Jambi Tribunnews. (2016). Aksi Simpati Dunia Maya untuk Yuyun, Siswi SMP yang Mati Usai Diperkosa 14 Pemuda.

Kurniawan, A. (2017). Analisis Hukuman Kebiri Terhadap Pelaku Pencabulan Anak Di Tinjau Dari Tujuan Pemidanaan. Poenale, 5(6), 12-13.

Metro. (2015). Pembunuhan Siswi Madrasah, IniKronologinya. Tempo, 1.

Muhammadiyah.or.id. (2021). Hukuman Kebiri Pada Pelaku Kekerasan Seksual Pada Anak, Ketum NA: Perlu Dikritisi! Https://MuhammadiYah.or.Id/Hukuman-Kebiri-Pada-Pelaku-Kekerasan- Seksual-Pada-AnakKetum-Na-Perlu-Dikritisil, 1.

Munthe, C. A. (2016). Relevansi sanksi kebiri kimia dalam perpu no. 1 tahun 2016 tentang perubahan kedua atas undang-undang nomor 23 tahun 2002 tentang perlindungan anak terhadap tujuan pemidanaan. Jurnal Hukum Justitia Et Pax, 32(2), 106-122.

NUonline. (2019). NU Jatim Haramkan Hukuman Kebiri Kimia bagi Pelaku Pencabulan. Https://Www.Nu.or.Id/Post/Read/110442/Nu-Jatim-HaRamkan-Hukuman-Kebiri-Kimia-Bagi-Pelaku-Pencabu-Lan.

Rodliyah, Al-Husaini, M., \& Hamzah, A. S. (2020). Hukuman Kebiri Terhadap Pelaku Kejahatan Pedofilia dalam Undang-Undang Nomor 7 Tahun 2016 Tentang Perlindungan Anak. Jurnal Dinamika Sosial Budaya, 22(2), 129139. 